\section{World Council of Churches}

The World Council of Churches was formally constituted on 23 Aug. 1948 in Amsterdam. In Feb. 2014 member churches numbered 360 from around 150 countries.

Origin. The World Council was founded by the coming together of Christian movements, including the overseas mission groups gathered from 1921 in the International Missionary Council, the Faith and Order Movement, and the Life and Work Movement. On 13 May 1938, at Utrecht, a provisional committee was appointed to prepare for the formation of a World Council of Churches.

Membership. The basis of membership (1975) states: 'The World Council of Churches is a fellowship of Churches which confess the Lord Jesus Christ as God and Saviour according to the Scriptures and therefore seek to fulfil together their common calling to the glory of the one God, Father, Son and Holy Spirit.' Membership is open to Churches which express their agreement with this basis and satisfy such criteria as the Assembly or Central Committee may prescribe. Today, Churches of Protestant, Anglican, Orthodox, Old Catholic and Pentecostal confessions from all over the world belong to this fellowship. The Roman Catholic Church is not a member of the WCC but works closely with it.

Activities. The WCC's Central Committee comprises the Programme Committee and the Finance Committee. Within the Programme Committee there are advisory groups on issues relating to communication, women, justice, peace and creation, youth, ecumenical relations and inter-religious relations. Following the WCC's 8th General Assembly in Harare, Zimbabwe in 1998 the work of the WCC was restructured. Activities were grouped into four 'clusters'-Relationships; Issues and Themes; Communication; and Finance, Services and Administration. The Relationships cluster comprises four teams (Church and Ecumenical Relations, Regional Relations and Ecumenical Sharing, Inter-Religious Relations and International Relations), as well as two programmes (Action by Churches Together and the Ecumenical Church Loan Fund). The Issues and Themes cluster comprises four teams (Faith and Order; Mission and Evangelism; Justice, Peace and Creation; and Education and Ecumenical Formation).

Organization. The governing body of the World Council, consisting of delegates specially appointed by the member Churches, is the Assembly, which meets every seven or eight years to frame policy. It has no legislative powers and depends for the implementation of its decisions upon the action of member Churches. The 10th General Assembly, held in Busan, South Korea from 30 Oct. -8 Nov. 2013, had as its theme 'God of life, lead us to justice and peace'. A 159-member Central Committee meets annually to carry out the Assembly mandate, with a smaller 26-member Executive Committee meeting twice a year.

Headquarters: PO Box 2100, 150 route de Ferney, CH-1211 Geneva 2, Switzerland.

Website: http://www.oikoumene.org

General Secretary: Rev. Dr Olav Fykse Tveit (Norway).

Publications. Annual Reports; Dictionary of the Ecumenical Movement, Geneva, 1991; Directory of Christian Councils, 1985; A History of the Ecumenical Movement, Geneva, 1993; Ecumenical Review (quarterly); Ecumenical News International (weekly); International Review of Mission (quarterly).

\section{Further Reading}

Castro, E., A Passion for Unity. 1992

Raiser, K., Ecumenism in Transition. 1994

Van Elderen, M. and Conway, M., Introducing the World Council of Churches. 1991

\section{World Customs Organization}

Established in 1952 as the Customs Co-operation Council, the World Customs Organization is an intergovernmental body with worldwide membership, whose mission it is to enhance the effectiveness and efficiency of customs administrations throughout the world. It has 179 member countries or territories.

Headquarters: Rue du Marché, 30, B-1210 Brussels, Belgium.

Website: http://www.wcoomd.org

Secretary-General: Kunio Mikuriya (Japan).

\section{World Federation of Trade Unions (WFTU)}

Origin and History. The WFTU was founded on a worldwide basis in 1945 at the international trade union conferences held in London and Paris, with the participation of all the trade union centres in the countries of the anti-Hitler coalition. The aim was to reunite the world trade union movement at the end of the Second World War. The acute political differences among affiliates, especially the east-west confrontation in Europe on ideological lines, led to a split. A number of affiliated organizations withdrew in 1949 and established the ICFTU. The WFTU now draws its membership from the industrially developing countries like India, Vietnam and other Asian countries, Brazil, Peru, Cuba and other Latin American countries, Syria, Lebanon, Kuwait and other Arab countries, and it has affiliates and associates in more than 20 European countries. It has close relations with the International Confederation of Arab Trade Unions, the Organization of African Trade Union Unity as well as the All-China Federation of Trade Unions. The 16th Congress was held in Athens, Greece in April 2011. Its Trade Unions Internationals (TUIs) have affiliates in Russia, the Czech Republic, Poland and other East European countries, Portugal, France, Spain, Japan and other OECD countries.

The headquarters of the TUIs are situated in Helsinki, New Delhi, Budapest, Mexico, Paris and Moscow. The WFTU has $120 \mathrm{~m}$. members in 80 countries. It has regional offices in Dakar, Damascus, Havana, Johannesburg, Moscow, New Delhi and Nicosia and Permanent Representatives accredited to the UN in New York, Geneva, Paris and Rome.

Headquarters: 40 Zan Moreas St., 11745 Athens, Greece.

Website: http://www.wftucentral.org

Email: info@wftucentral.org

President: Mohammad Assouz (Syria).

General Secretary: George Mavrikos (Greece).

Publications. Flashes From the Trade Unions (fortnightly, published in English, French, Spanish and Arabic), reports of Congresses, etc.

\section{African Development Bank}

Established in 1964 to promote economic and social development in Africa.

Regional members. (54) Algeria, Angola, Benin, Botswana, Burkina Faso, Burundi, Cabo Verde, Cameroon, Central African Republic, Chad, Comoros, Democratic Republic of the Congo, Republic of the Congo, Côte d'Ivoire, Djibouti, Egypt, Equatorial Guinea, Eritrea, Ethiopia, Gabon, Gambia, Ghana, Guinea, Guinea-Bissau, Kenya, Lesotho, Liberia, Libya, Madagascar, Malawii, Mali, 